\title{
ŠTRUKTÚRA PERSONÁLNEJ VYBAVENOSTI ÚRADOV MIESTNEJ SAMOSPRÁVY V PODMIENKACH SLOVENSKEJ REPUBLIKY
}

\section{THE STRUCTURE OF PERSONAL FACILITIES LOCAL GOVERNMENT OFFICES IN THE SLOVAK REPUBLIC}

\section{ING. IVANA GECÍKOVÁ, PHD. ${ }^{1}$}

\section{DOC. ING. VIERA PAPCUNOVÁ, PHD. ${ }^{2}$}

\author{
${ }^{1}$ Katedra verejnej správy, Ústav pre verejnú správu $\mid{ }^{1}$ Public Administration Institute \\ Vysoká škola ekonómie a manažmentu verejnej správy School of Economics and Management in Public \\ $\checkmark$ Bratislave Administration in Bratislava \\ $\triangle$ Furdekova 16, 84104 Bratislava, Slovak Republic \\ E-mail: ivana.gecikova@vsemvs.sk \\ ${ }^{2}$ Ústav manažmentu a informačných technológii, $\quad{ }^{2}$ Institute of Manag. and Information Technology \\ Fakulta prírodných vied Faculty of Natural Sciences \\ Univerzita Konsttantína Filozofa v Nitre Constantine the Philosopher University in NItra \\ $\bowtie \operatorname{Tr}$. A. Hlinku 1, 94974 Nitra, Slovak Republic \\ E-mail:vpapcunova@ukf.sk
}

\begin{abstract}
Anotácia
Procesom decentralizácie kompetencií zo štátnej správy na obce sa vytvoril a neustále pôsobí tlak na pracovníkov úradov miestnej samosprávy, aby svoju prácu vykonávali na vysokej profesionálnej úrovni a aby si permanentne zvyšovali svoju odbornost' pri výkone činností spadajúcich do agendy obecných a mestských úradov. Výsledky výskumu prezentované v príspevku poukazujú na jednej strane na štruktúru zamestnancov úradov miestnej samosprávy a ich zapojenie sa do procesov odborného vzdelávania. Na druhej strane sa príspevok zameriava aj na poznanie názorov a postojov na pristup a profesionalizáciu pracovníkov úradov miestnej samosprávy očami občana - klienta, ktorý si danú službu objednáva.
\end{abstract}

\section{Kl'účové slová}

miestna samospráva, úradnici, profesionalizácia, školenia

\section{Annotation}

The decentralization process of competences from state administration to municipalities created and continuously operates the pressure on officials of local self-governments to carry out their work on a high professional level and continuously improve their expertise in carrying out activities falling under the administration of the municipal offices. The research results presented in this paper, show on the one hand on structure of the local self-government employees and their involvement in the training process. On the other hand, the paper also focuses on knowing the opinions and attitudes of access and professionalism of local self-governments officials through the eyes of a citizen - a client who ordered the service.

Key words

local self-government, officials, professionalism, training

JEL classification: $H 11$ 


\section{Úvod}

Obecný (mestský) úrad so svojim zamestnancami zabezpečuje administratívne a organizačné veci obecného (mestského) zastupitel'stva a starostu (primátora), ako aj d’alších zriadených orgánov. Je tvorený z pracovníkov obce (mesta). Je výkonným orgánom pre zastupitel'stvo a starostu (primátora). Pracovný poriadok, organizačný poriadok obecného úradu a poriadok odmeňovania zamestnancov obce, ako aj d'alšie interné smernice potrebné pre chod úradu vydáva starosta. Ten tiež aj informuje obecné (mestské) zastupitel'stvo o vydaní a zmenách organizačného poriadku obecného úradu. Obecný (mestský) úrad zabezpečuje písomnú agendu všetkým orgánom obce (mesta), je podatel'ňou a výpravňou písomností obce (mesta), zabezpečuje odborné podklady a iné písomností na rokovanie rady a zastupitel'stva. Okrem toho vypracúva písomné vyhotovenia všetkých rozhodnutí starostu (primátora) V správnom konaní a vykonáva nariadenia, uznesenia obecného (mestského) zastupitel'stva a rozhodnutia starostu.

Prácu obecného úradu riadi starosta. $\mathrm{V}$ obciach $\mathrm{s}$ väčším počtom zamestnancov môže byt' zriadená funkcia prednostu obecného úradu. Ak je v obci zriadená funkcia prednostu obecného úradu, obecný úrad vedie a jeho prácu organizuje prednosta.

Funkcia prednostu obecného (mestského) úradu je príkladom menovaného manažéra v podmienkach miestnej samosprávy. Prednostu vymenúva a odvoláva starosta. Kritickým článkom medzi vrcholným vedením a výkonnými zamestnancami je stredný manažment. Ten ako prvý by mal akceptovat' zodpovednost' za proces zlepšenia, je hlavným motorom zlepšovania a nositel'om kvality. V prípade miestnej samosprávy sú to vo vel'kých obciach a v mestách vedúci odborov, riaditelia organizácií zriadených obcou atd'.

Hodnotenie kvality je významným prvkom pri poskytovaním služieb miestnou samosprávou. Z praktického hl'adiska to znamená nevyhnutne zvyšovat' kvalitu života občanov a poskytovat' im kvalitné služby, ale ako uvádzajú Mateides - Závadský (2005), je dôležité, aby občania kvalitu nielen vnímali, ale aby boli aj spokojní. Podl’a Balážovej -Papcunovej (2008) bežného občana nezaujíma ekonomická výkonnost' samotnej samosprávy. Skôr si všímajú nevýkonnost' ako nekvalitu, pomalost', neochotu, nekompetentnost', nefunkčnost' atd'. Riadeniu kvality poskytovaných služieb sa venujú mnohí autori. Treba si však uvedomit', že kvalita poskytovaných služieb úzko súvisí s kvalitou samosprávneho manažmentu. Len profesionálne a odborne pripravený úradník je schopný naplnit' všetky predpoklady pre poskytovanie kvalitných služieb na úrovni miestnej samosprávy.

\section{Materiál a metódy}

Ciel’om príspevku je na jednej strane zhodnotit' štruktúru zamestnancov úradov miestnej samosprávy a ich zapojenie sa do procesov odborného vzdelávania. Na druhej strane ide aj o poznanie názorov a postojov na prístup a profesionalizáciu pracovníkov úradov miestnej samosprávy očami občana klienta, ktorý si danú službu objednáva.

V období september - november 2011 sme uskutočnili dotazníkový prieskum, ktorý bol zameraný na poznanie štruktúry obecných úradov $\mathrm{v}$ obciach rôznej vel'kosti a na prístup jednotlivých obcí na zvyšovanie odbornosti svojich úradníkov. Do dotazníkového prieskumu bolo zapojených 285 obcí Slovenska. Výber obcí bol realizovaný náhodným výberom. Najpočetnejšou skupinou v prieskume boli obce s počtom obyvatel'ov od 1000 do 2999, ktorých bolo 111 (38,9 \%) a najmenšiu skupinu tvorili obce s počtom obyvatel'ov nad 5000 (2,8 \%). Samostatne sme hodnotili obce, ktoré majú udelený štatút mesta a mestské časti. Mestské časti v mestách Bratislava a Košice majú na výkon samosprávnych kompetencií zriadené miestne úrady, preto sme ich z hl'adiska nášho prieskumu hodnotili ako samostatné obce. Štruktúra jednotlivých vel'kostných kategórií obcí a ich početnost' je uvedená $\mathrm{v}$ grafe 1 . 


\section{Graf 1: Štruktúra obcí zapojených do prieskumu (abs.)}

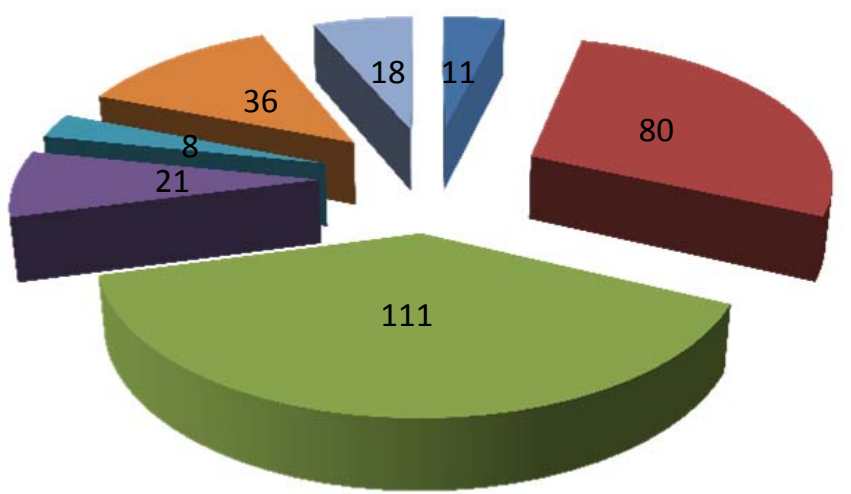

$$
\begin{aligned}
& \text { do } 299 \text { (1) } \quad 300 \text { - } 999 \text { (2) } \quad 1000-2999 \text { (3) } \quad 3000-4999 \text { (4) } \\
& \text { nad } 5000 \text { (5) घ mestá (6) mestské časti (7) }
\end{aligned}
$$

Zdroj: dotazníkový prieskum, vlastné spracovanie Vysvetlivky: číslo v zátvorke vyjadruje vel'kostnú kategóriu obcí (od 1 - najmenšie obce; 7 - mestské časti)

V tom istom období sme realizovali tiež dotazníkový prieskum na identifikáciu kritérií, podl’a ktorých si obyvatelia vyberajú svojich volených zástupcov. Dotazníkového prieskumu sa zúčastnilo 112 respondentov. $Z$ celkového počtu respondentov bolo 89 žien (79,5\%) a 23 mužov (20,5\%).

\section{Graf 2: Štruktúra respondentov (v \%)}

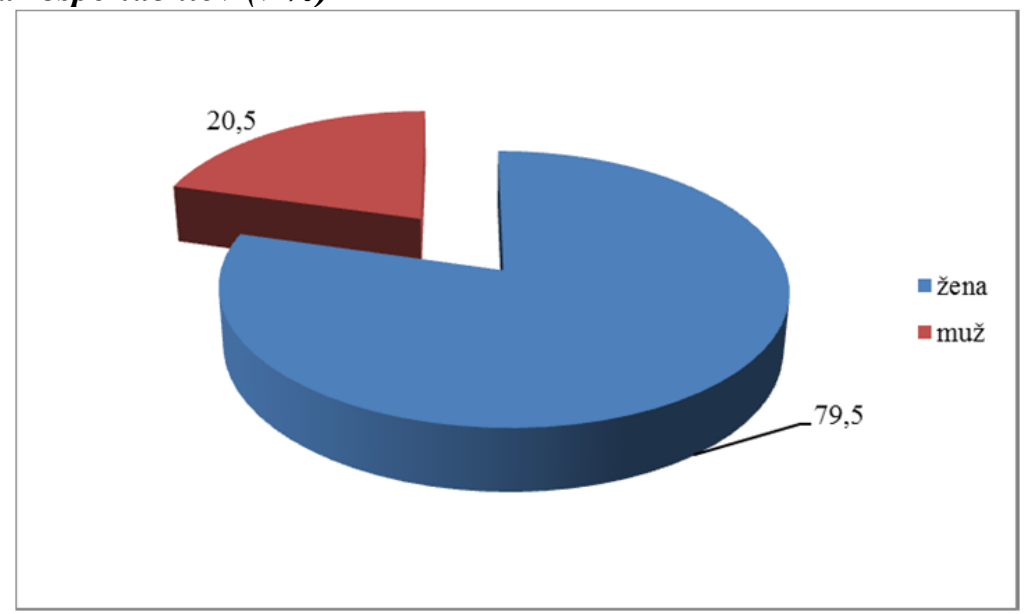

Zdroj: dotazníkový prieskum, vlastné spracovanie

V rámci vekovej štruktúry najväčší podiel respondentov bol vo veku 26 - 40 rokov (57 osôb, čo predstavovalo 50,9\%), druhou najsilnejšou skupinou boli respondenti vo veku do 25 rokov (38 osôb, čo predstavuje 33,9\%). Vo veku $41-55$ rokov bolo 16 respondentov (14,3\%), vo veku $56-65$ rokov bol iba jeden respondent $(0,9 \%)$. 


\section{Graf 3: Veková štruktúra respondentov (v \%)}

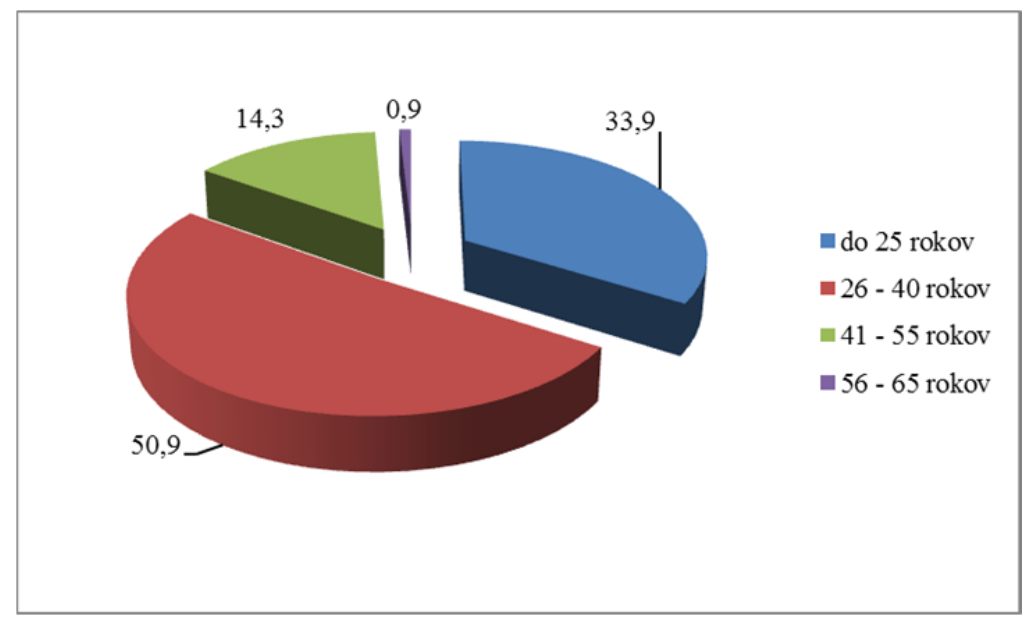

Zdroj: dotaznikový prieskum, vlastné spracovanie

Najväčší počet respondentov malo ukončené I. stupeň vysokoškolského štúdia ( 85 respondentov, čo predstavovalo 75,9\%). Úplne stredoškolské vzdelanie s maturitou malo 24 respondentov $(21,4 \%)$, iba 3 respondenti mali ukončené vysokoškolské vzdelanie II. stupňa.

\section{Graf 4: Vzdelanie respondentov (v \%)}

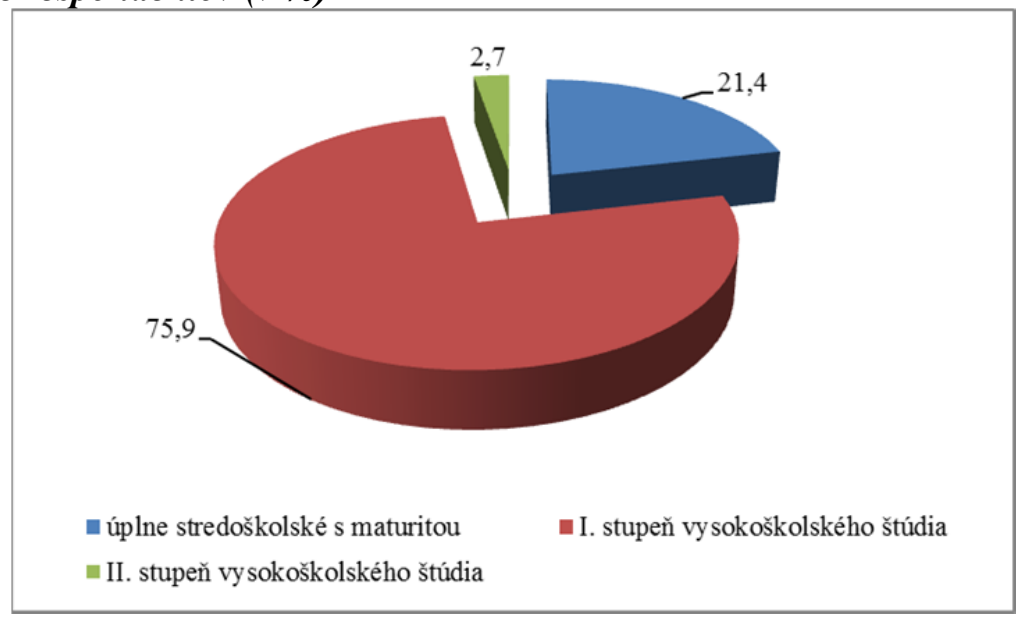

Zdroj: dotaznikový prieskum, vlastné spracovanie

\section{Výsledky}

$\mathrm{Na}$ obecných úradoch obcí zapojených do prieskumu pracovalo 7456 zamestnancov. Počet zamestnancov sa $\mathrm{v}$ jednotlivých kategóriách obcí odlišoval. Ako vidiet' v tabul'ke 1, s rastúcim počtom obyvatel'ov rástol aj počet zamestnancov na úrade miestnej samosprávy. Avšak priemerný počet zamestnancov vykazoval $\mathrm{s}$ rastúcim počtom obyvatel'ov v obciach pokles. Túto skutočnost' potvrdil aj d'alší z ukazovatel'ov: počet zamestnancov pripadajúcich na 1000 obyvatel'ov. Vidiet', že čím je obec väčšia, tým je počet zamestnancov pripadajúcich na 1000 obyvatel’ov menšia. Výsledky prieskumu poukázali, že obslužnost' personálu pri poskytovaní služieb miestnej samosprávy je s rastúcim počtom obyvatel'ov vyššia vo väčších obciach a mestách, ako v malých dedinách. 
Tab. 1: Prehl'ad počtu zamestnancov obecných a mestských úradov zapojených do prieskumu (v abs.)

\begin{tabular}{|c|c|c|c|c|c|}
\hline $\begin{array}{c}\text { Počet } \\
\text { obyvatel'ov } \\
\text { (kategória obce) }\end{array}$ & počet obcí & $\begin{array}{c}\text { počet } \\
\text { obyvatel'ov } \\
\text { spolu }\end{array}$ & \begin{tabular}{|c} 
počet \\
zamestnancov \\
spolu
\end{tabular} & $\begin{array}{l}\text { priem. počet } \\
\text { zamest./obec }\end{array}$ & $\begin{array}{c}\text { počet } \\
\text { zamestnancov/1000 } \\
\text { obyv. }\end{array}$ \\
\hline do 299 (1) & 11 & 2295 & 38 & 3,45 & 16,56 \\
\hline $300-999(2)$ & 80 & 50971 & 504 & 6,30 & 9,89 \\
\hline $1000-2999(3)$ & 111 & 190505 & 1542 & 13,89 & 8,09 \\
\hline $3000-4999(4)$ & 21 & 80138 & 547 & 26,05 & 6,83 \\
\hline $\operatorname{nad} 5000(5)$ & 8 & 47240 & 296 & 37,00 & 6,27 \\
\hline mestá (6) & 36 & 1288546 & 3395 & 94,31 & 2,63 \\
\hline mestské časti (7) & 18 & 496145 & 1254 & 69,67 & 2,53 \\
\hline
\end{tabular}

Z hladiska štruktúry zamestnancov sme skúmali, aký je podiel zamestnancov podla pohlavnej štruktúry a podl'a charakteru pracovného pomeru. Zistili sme, že okrem malých obcí do 299 obyvatel'ov v úradoch miestnej samosprávy pracujú najmä ženy. Vel'kostná kategória obce tu nezohráva žiadnu úlohu. Z hl'adiska pracovného úväzku sú v každej vel'kostnej kategórií obcí zamestnaní s viac ako $60 \%$ podielom zamestnanci na plný (100\%) pracovný úväzok. Najnižší podiel takýchto zamestnancov bol zaznamenaný v kategórii malých obcí do 299 obyvatel'ov. Je to však pochopitel'né aj z hl'adiska ich možností obslužnosti obyvatel'stva, nižšieho počtu činností, ktoré vykonávajú, ako aj limitov určených rozpočtom obce. Zvyšná čast' zamestnancov je zamestnaná na dohody. V tomto prípade sa jedná o profesie, ktoré sú úzko špecializované, ale frekvencia ich výskytu na obci nie je často opakujúcou sa (pravidelne opakujúcou môže byt' - napr. metodická pomoc pri prevádzke obecného vodovodu). Obce zamestnávajú aj pracovníkov so zníženou pracovnou schopnost'ou. Najvyšší podiel sme zistili v kategórií obcí 5 - obce nad 5000 obyvatel'ov. Ich podiel tvoril na celkovom počte zamestnancov až $6,76 \%$.

Tab. 2: Podiel vybraných kategórií zamestnancov na celkovom počte zamestnancov podl'a vel'kostných kategórií obcí (v \%)

\begin{tabular}{|c|c|c|c|c|c|c|}
\hline $\begin{array}{lr}\text { kategória } & \text { obce } \\
\text { (podl'a } & \text { počtu } \\
\text { obyvatel'ov) }\end{array}$ & $\begin{array}{l}\text { podiel } \\
\text { mužov }\end{array}$ & $\begin{array}{l}\text { podiel } \\
\text { žien }\end{array}$ & $\begin{array}{c}\text { podiel } \\
\text { zamestn. } \\
\text { na } 100 \% \\
\text { pracovný } \\
\text { úväzok }\end{array}$ & $\begin{array}{c}\text { podiel } \\
\text { zamest. na } \\
\text { čiastočný } \\
\text { pracovný } \\
\text { úväzok }\end{array}$ & $\begin{array}{c}\text { podiel zamest. } \\
\text { na mimo } \\
\text { pracovný } \\
\text { úväzok }\end{array}$ & $\begin{array}{c}\text { podiel zamest. } \\
\text { so zníženou } \\
\text { prac.schopnos } \\
\text { t'ou }\end{array}$ \\
\hline do 299 (1) & 52,63 & 47,37 & 60,53 & 65,79 & 39,47 & 0,00 \\
\hline \begin{tabular}{|l|}
$300-999(2)$ \\
\end{tabular} & 32,94 & 66,27 & 67,86 & 25,20 & 6,55 & 4,76 \\
\hline $1000-2999(3)$ & 42,54 & 62,26 & 79,31 & 13,68 & 10,77 & 3,44 \\
\hline $3000-4999(4)$ & 40,77 & 59,23 & 68,92 & 16,64 & 18,10 & 4,57 \\
\hline nad $5000(5)$ & 31,42 & 68,58 & 75,68 & 21,96 & 6,42 & 6,76 \\
\hline mestá (6) & 33,76 & 65,30 & 85,30 & 9,60 & 20,85 & 3,18 \\
\hline $\begin{array}{l}\text { mestské časti (7) } \\
\end{array}$ & 27,99 & 72,09 & 84,37 & 5,98 & 18,58 & 2,59 \\
\hline
\end{tabular}

$\mathrm{Na}$ základe dotazníkového prieskumu môžeme skonštatovat', že pravidlo s rastúcim počtom obyvatel'ov rastie aj počet pracovníkov úradov, sa nepotvrdilo. Ako prezentuje tabul'ka 3, vo všetkých skúmaných kategóriách zamestnancov klesá počet zamestnancov pripadajúcich na 1000 obyvatel'ov. Výnimku nachádzame len pri pracovníkoch pracujúcich na dohody mimo hlavného pracovného pomeru a pri zamestnancoch so zníženou pracovnou schopnost'ou. 
Tab. 3: Počet vybraných kategórií zamestnancov obecných a mestských úradov na 1000 obyvatel'ov (vabs.)

\begin{tabular}{|c|r|r|r|r|r|r|r|}
\hline $\begin{array}{c}\text { kategóri } \\
\text { a obce }\end{array}$ & $\begin{array}{c}\text { počet } \\
\text { zames./1000 } \\
\text { obyv. }\end{array}$ & $\begin{array}{c}\text { počet } \\
\text { zames. } \\
\text { mužov/1000 } \\
\text { obyv. }\end{array}$ & $\begin{array}{c}\text { počet } \\
\text { zames. } \\
\text { żien/100 } \\
\mathbf{0} \text { obyv. }\end{array}$ & $\begin{array}{c}\text { počet } \\
\text { zames.100 \% } \\
\text { úväzok/1000 } \\
\text { obyv. }\end{array}$ & $\begin{array}{c}\text { počet zames. } \\
\text { čiast.úväzok/ } / \\
\mathbf{1 0 0 0} \text { obyv. }\end{array}$ & $\begin{array}{c}\text { počet } \\
\text { zames. } \\
\text { dohodárov/ } \\
\mathbf{1 0 0 0} \text { obyv. }\end{array}$ & $\begin{array}{c}\text { počet } \\
\text { zames.ZŤP/ } \\
\mathbf{1 0 0 0} \text { obyv. }\end{array}$ \\
\hline 1 & 16,6 & 8,71 & 7,84 & 10,02 & 10,89 & 6,54 & 0,00 \\
\hline 2 & 9,89 & 3,26 & 6,55 & 6,71 & 2,49 & 0,65 & 0,47 \\
\hline 3 & 8,09 & 3,44 & 5,04 & 6,42 & 1,11 & 0,87 & 0,28 \\
\hline 4 & 6,83 & 2,78 & 4,04 & 4,70 & 1,14 & 1,24 & 0,31 \\
\hline 5 & 6,27 & 1,97 & 4,30 & 4,74 & 1,38 & 0,40 & 0,42 \\
\hline 6 & 2,63 & 0,89 & 1,72 & 2,25 & 0,25 & 0,55 & 0,08 \\
\hline 7 & 2,53 & 0,71 & 1,82 & 2,13 & 0,15 & 0,47 & 0,07 \\
\hline
\end{tabular}

Zdroj: dotazníkový prieskum, vlastné spracovanie

Služby, ktoré poskytuje miestna samospráva sú poskytované zamestnancami obecných (mestských) úradov. Aby tieto služby boli poskytované odborne a vysoko profesionálne, existuje celá škála inštitúcií, ktoré pripravujú školenia pre odborných zamestnancov úradov. Zaujímalo nás, ako sa jednotlivé obce stavajú k vzdelávaniu zamestnancov a či ich na školenia vysielajú.

\section{Graf 5: Zapojenie obcí do odborného vzdelávania zamestnancov (v \%)}

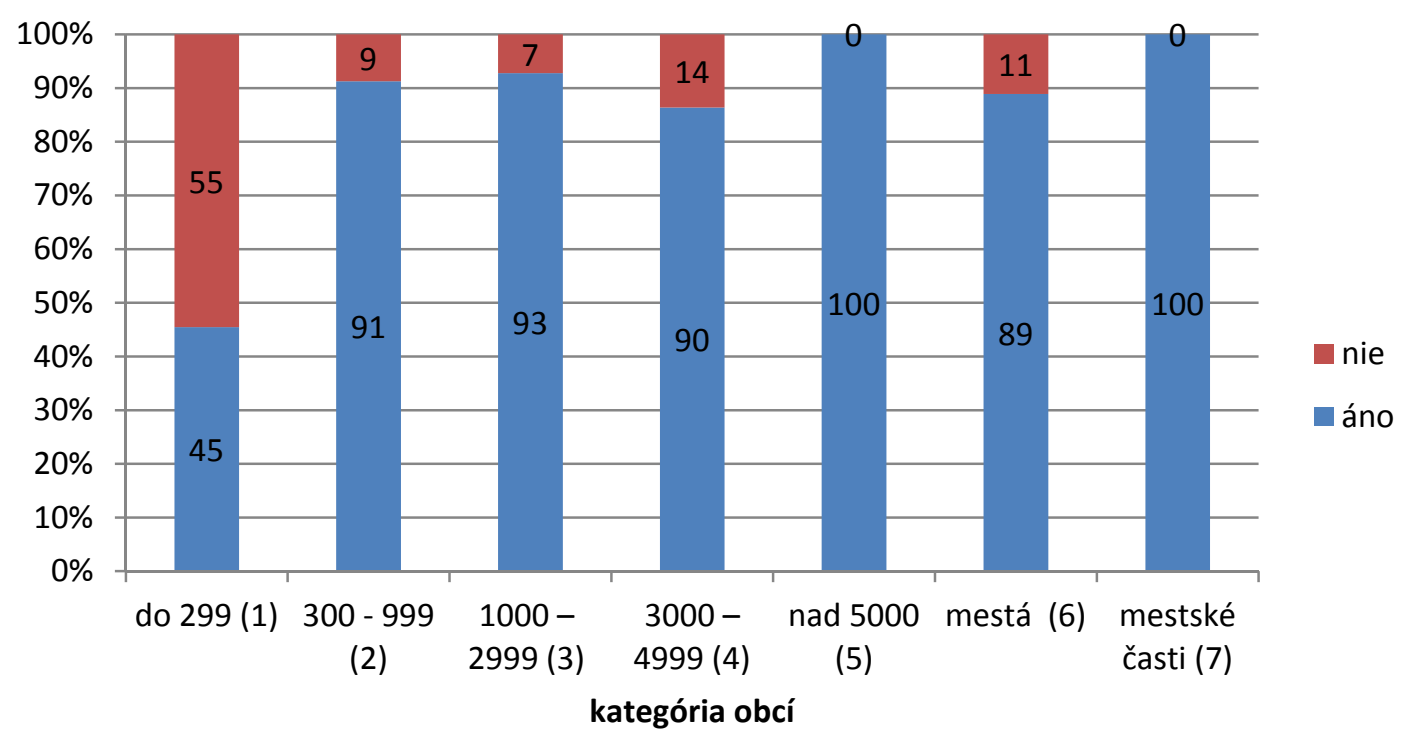

Zdroj: dotaznikový prieskum, vlastné spracovanie

Výskumom sme zistili, že obce sa zaujímajú o danú problematiku (viac ako 90 \% skúmaných obcí) a svojich zamestnancov vysielajú na všetky aktuálne školenia, a to najmä pri zmene zákonov. Jedinou výnimkou je kategória obcí 1 - obce do 299 obyvatel'ov. Dôvodom sú nielen finančné obmedzenia vychádzajúce z rozpočtov týchto obcí, ale aj skutočnost', že niektoré činnosti, ktoré sa vyskytovali ako najčastejšie školené, sa v malých obciach vôbec nevyskytujú (napr. oblast' matriky), resp. sú vykonávané externou firmou, ktorá si zamestnancov školí vo svojej vlastnej réžii (napr. pozícia ekonóma a účtovníka).

Ako bolo naznačené $\mathrm{v}$ predchádzajúcom texte, pri každodennom riešení svojich problémov sa obyvatelia častejšie stretávajú s pracovníkmi úradu ako s poslancami alebo starostom obce. Preto v tejto otázke respondenti vyjadrovali svoj názor na pracovníkov úradu. Pomerne pozitívne hodnotili spôsob komunikácie s občanmi, kedy až $31,3 \%$ je spokojných a 47,3\% je skôr spokojných ako 
nespokojných s tým ako sa $\mathrm{k}$ nim správajú pracovníci úradu ked' prichádzajú k nim riešit' svoje problémy. Pozitívne respondenti hodnotili aj zodpovednost', odborný prístup k riešeniu ich problémov a ústretovost' pracovníkov. Až 71,4\% respondentov bolo vel'mi spokojných resp. skôr spokojných ako nespokojných so zodpovedným prístupom k plneniu úloh, $63,4 \%$ respondentov bolo spokojných resp. skôr spokojných ako nespokojných sodbornost'ou pracovníkov a 73,2\% respondentov bolo spokojných resp. skôr spokojných ako nespokojných s ústretovost’ou pracovníkov úradu.

\section{Graf 5: Hodnotenie pracovnikov obecného/mestského úradu (v \%)}

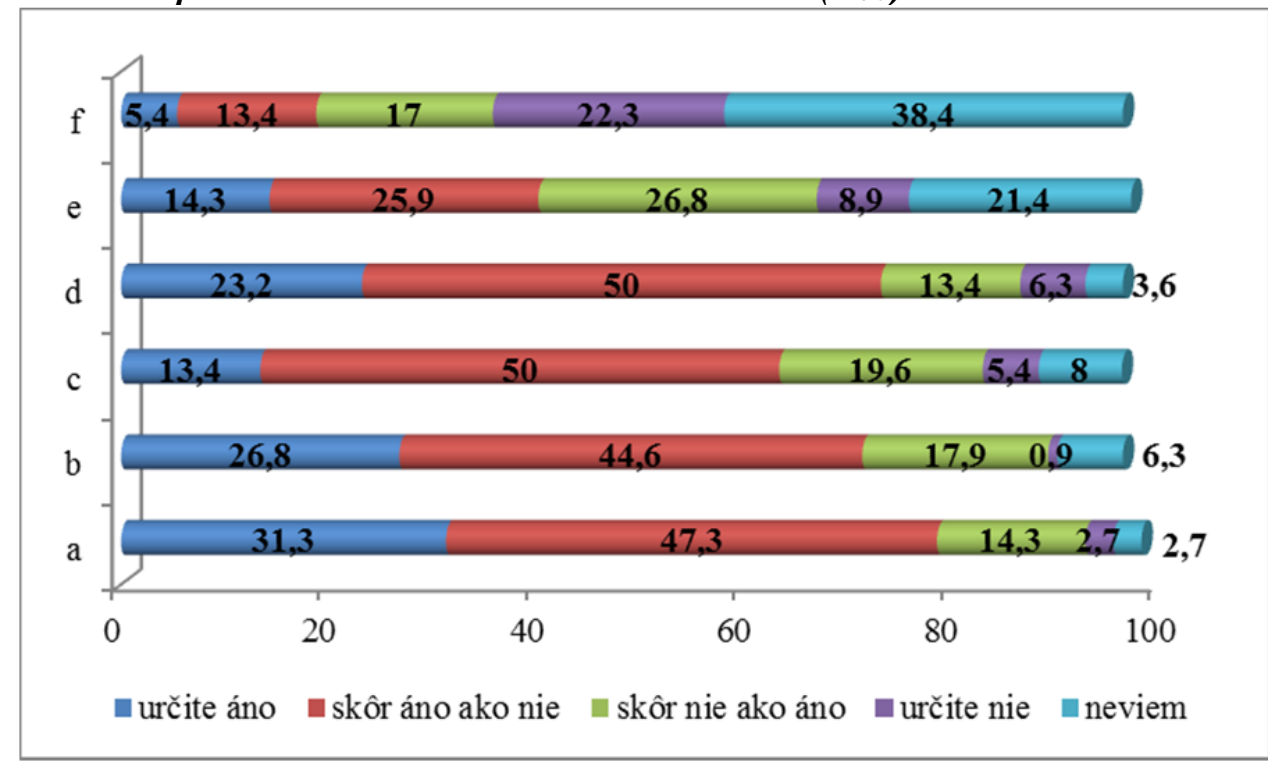

Zdroj: dotazníkový prieskum, vlastné spracovanie

Legenda: a- spôsob komunikácie s občanmi, b - zodpovedný prístup k plneniu úloh, c - odbornost', d - ústretovost', $\mathrm{e}$ - osobný prospech $\mathrm{z}$ práce na úrade, $\mathrm{f}$ - neštítia sa zobrat' úplatok

Respondenti hodnotili aj to, či pracovníci majú osobný prospech z práce na úrade resp. či zoberú úplatok za rýchlejšie vyriešenie problému. Iba $8,9 \%$ respondentov je presvedčených, že pracovníci nemajú žiadny osobný prospech resp. prospech z práce na úradu, $21,4 \%$ nevedelo na túto otázku odpovedat' a až $35,7 \%$ respondentov si myslí, že pracovníci úradu majú osobný prospech z práce na úrade.

Zaujímavá je skutočnost', že až 38,4\% respondentov sa nevedelo vyjadrit', či by boli pracovníci schopní zobrat' úplatok. $Z$ uvedeného hodnotenia je možné dedukovat', že zrejme títo respondenti pri styku s pracovníkmi úradu neponúkali úplatok pracovníkom úradu. Pozitívom je aj skutočnost', že 39,3\% respondentov je presvedčených, že by určite resp. skôr nie ako áno s úplatkom neboli úspešní. $18,8 \%$ respondentov je presvedčených, resp. uviedli, že skôr áno ako nie by boli pracovníci úradu schopní prijat' úplatok za prednostné vyriešenie ich problému.

\section{Záver}

Úrady miestnej samosprávy zohrávajú pri zabezpečovaní samosprávnych činností obcí nezastupitel'nú úlohu. Na jednej strane predstavujú administratívne centrum celej obce počnúc podatel'nou a výpravňou písomností až po administráciu, prípravu a vykonávanie komplexných obecných rozhodnutí. Obecné úrady a ich činnost' je reprezentovaná najmä štruktúrou zamestnancov, ktorí $\mathrm{v}$ ňom pracujú. $\mathrm{V}$ príspevku sme poukázali nielen na počet zamestnancov úradov, ale zist'ovali sme aj ich pohlavnú štruktúru, druh zamestnaneckého pomeru a zapojenost' zamestnancov so zníženou pracovnou schopnost'ou. Výsledky výskumu poukázali na skutočnost', že s rastúcim počtom obyvatel'ov v obciach dochádza $\mathrm{k}$ nárastu počtu zamestnancov na úradoch $\mathrm{v}$ miestnej samospráve. V malých obciach, najmä tých do 299 obyvatel'ov, je priemerný počet zamestnancov na obec najmenší. Naopak v mestách a vo vel'kých obciach je počet zamestnancov najvyšší. Táto situácia je podmienená najmä rozsahom činností, ktoré konkrétny úrad vykonáva. Aj napriek skutočnosti, že 
všetky miestne samosprávy majú zákonom stanovený rovnaký okruh pôsobností, niektoré úseky (napr. úsek matriky) sa v malých obciach nevykonávajú. V praxi sa vyskytujú aj prípady, že pracovníci úradu na malej obci sa s niektorými činnost’ami nestretli aj niekol'ko rokov, čo však v prípade vel'kých obcí a miest je naopak. Výskum poukázal, ž vel'ké obce a mestá majú omnoho vyššiu obslužnost' obyvatel'stva v porovnaní s malými obcami. Na 1000 obyvatel'ov malých obcí pripadá až 8,71 zamestnancov (obce do 299 obyvatel'ov) a 3,44 zamestnancov (obce s počtom obyvatel'ov od 1000 do 2999).

Občania obecné a mestské úrady vnímajú najmä v čase, ked' sa priamo dopytujú po konkrétnych službách poskytovaných miestnou samosprávou. Majú záujem byt' vybavený rýchlo, vysoko odborne a najmä $\mathrm{v}$ ich prospech. Zistili sme, že miestne samosprávy majú záujem o profesionalitu pri poskytovaní služieb a preto $\mathrm{v}$ rámci odborného vzdelávania zamestnancov vyše $90 \%$ dotazovaných obcí vysiela svojich zamestnancov na rôzne školenia a semináre. Túto skutočnost' nám potvrdili aj výsledky výskumu zameraného na spokojnost' obyvatel'ov so službami obecných a mestských úradov. Viac ako 71,4 \% opýtaných obyvatel'ov vyjadrilo spokojnost' so zodpovedným prístupom zamestnancov k plneniu úloh a 73,2 \% respondentov bolo spokojných s ústretovost’ou zamestnancov.

\section{Literatúra}

[1] BALÁŽOVÁ, E. , PAPCUNOVÁ, V. Manažment samospráv. 1.vyd. Žilina: Municipalia, 2008. 134 s. ISBN 978-80-552-0045-3.

[2] MATEIDES, A., ZÁVADSKÝ, J. Ako zaviest' systém riadenia kvality podl'a STN EN ISO 90012001 v organizácii. Bratislava: EPOS, 2005. 217 s. ISBN 80-8057-632-7.

[3] PAPCUNOVÁ, V., GECÍKOVÁ, I. 2012. Kritériá ovplyvňujúce občanov pri vol’be poslancov obecných a mestských zastupitel'stiev. In Ekonomické aspekty vúzemnej samospráve III. Recenzovaný zbornik príspevkov z vedeckej konferencie. Košice: UPJŠ, 2012. str. 45 - 54. ISBN978-80-8129-015-2.

[4] PAPCUNOVÁ, V., GECÍKOVÁ, I. 2011. Základy verejnej správy. Trenčín: IAV, 2011. 166 s. ISBN 978-80-970802-0-4 .

[5] Zákon č. 369/1990 Zb. o obecnom zriadení v z.n.p. 